\title{
Colchicine intoxication: a report of two suicide cases
}

This article was published in the following Dove Press journal:

Therapeutics and Clinical Risk Management

4 December 2013

Number of times this article has been viewed

\author{
Abdulsamet Erden' \\ Hatice Karagoz' \\ Hasan Hüseyin Gümüscü' \\ Samet Karahan' \\ Mustafa Basak' \\ Fatma Aykas' \\ Kadir Bulut' \\ Ali Cetinkaya' \\ Deniz Avci' \\ Orhan Kürsat Poyrazoglu² \\ 'Internal Medicine Department, \\ ${ }^{2}$ Gastroenterology Department, \\ Kayseri Training and Research \\ Hospital, Kayseri, Turkey
}

\begin{abstract}
Colchicine, an old and well-known drug, is an alkaloid extracted from Colchicum autumnale and related species. Colchicine inhibits the deposition of uric acid crystals and is an inhibitor of mitosis. Nausea, vomiting, abdominal pain, and diarrhea, with a massive loss of fluid and electrolytes are the first clinical symptoms of colchicine poisoning. Stomach lavage and rapid gastric decontamination with activated charcoal are crucial. An acute dose of about $0.8 \mathrm{mg} / \mathrm{kg}$ of colchicine is presumed to be fatal. We report the clinical outcomes of two different cases of colchicine intoxication for attempted suicide. The dose required for morbidity or mortality varies significantly. The dose of $1 \mathrm{mg} / \mathrm{kg}$ in the first case was directly related with mortality, while the dose of $0.2 \mathrm{mg} / \mathrm{kg}$ in the second was related with survival. The other difference between the patients was the time of arrival to hospital after ingestion. This period was 4 hours for case 1 and only 1, hour for case 2. The initiation of treatment later than 2 hours after ingestion of colchicine may significantly impair treatment because the absorption time for colchicine after oral administration is about 30-120 minutes. The rising lactate level and high anion gap metabolic acidosis in our patient (case 1) were attributed to lactic acidosis, so hemodialysis was performed, and the duration of hemodialysis was prolonged. Lactic acidosis in the first case was one of the reasons for mortality. The most important parameters which define the chance of survival are the dose of ingested drugs and the arrival time to hospital after ingestion. The patients must be monitored closely for lactic acidosis and the decision to start hemodialysis must be made promptly for patients who develop lactic acidosis.
\end{abstract}

Keywords: colchicine intoxication, metabolic acidosis, mortality

\section{Introduction}

Colchicine is an old and well-known drug, which is an alkaloid extracted from Colchicum autumnale and related species. It has an anti-inflammatory effect based on the ability to impair the mobility and activity of neutrophil leukocytes. In addition, colchicine inhibits the deposition of uric acid crystals and is an inhibitor of mitosis. It is a liposoluble alkaloid, which prevents the storage of amyloid, and it is used both in the management of acute gouty arthritis and familial Mediterranean fever (FMF). ${ }^{1}$ Presumably due to unidentified linkage sites with the microtubules of gastrointestinal cells, the absorption of colchicine is highly variable. Nausea, vomiting, abdominal pain, and diarrhea, with a massive loss of fluid and electrolytes are the first clinical symptoms of colchicine poisoning. ${ }^{2}$ As well as a cardiotoxic effect, reduced blood volume may also cause bradycardia. ${ }^{1}$ Stomach lavage and rapid gastric decontamination with activated charcoal have proven to be crucial measures of treatment. Ingestion of an acute dose of about $0.8 \mathrm{mg} / \mathrm{kg}$ of colchicine is thought to be fatal. ${ }^{3,4}$ We report the clinical
Correspondence: Samet Karahan Internal Medicine Department, Kayseri Training and Research Hospital, Kayseri Eğitim Araștırma Hastanesi, İç Hastalıkları Kliniği, 9 Blok 3, Kat Kocasinan, Kayseri, Turkey Tel +905063020036

Email doktorsamet@yahoo.com 
outcomes of two different cases of colchicine intoxication for attempted suicide.

\section{Case I}

A 23-year-old, $50 \mathrm{~kg}$ female patient was admitted to a local hospital with the complaints of nausea and vomiting 4 hours after taking $50 \mathrm{mg}$ or $1 \mathrm{mg} / \mathrm{kg}$ (100 tablets of $0.5 \mathrm{mg}$ ) colchicine for suicide. She had a history of FMF. Stomach lavage and activated charcoal gastric decontamination was performed, and she was transferred to the Kayseri Training and Research Hospital 10 hours after ingestion. She was conscious, orientated, and cooperative, and complained of diarrhea and abdominal pain. She had pale and cold skin, and her vital signs in the emergency facility revealed a blood pressure of $94 / 58 \mathrm{mmHg}$, body temperature of $36.8^{\circ} \mathrm{C}$, respiratory rate of 16 breaths/ minute, and heart rate of 77 beats/minute. She had tenderness on the epigastrium, and other system examinations were unremarkable. The patient was admitted to the intensive care unit. The results of initial laboratory studies were: white blood cells (WBC), $19.330\left(10^{3} \mu \mathrm{L}\right)$; hemoglobin, $15.4 \mathrm{~g} / \mathrm{dL}$; hematocrit, 45\%; platelets (PLTs), 250,000/ $\mathrm{mm}^{3}$; aspartate aminotransferase (AST), $87 \mathrm{U} / \mathrm{L}$; alanine aminotransferase (ALT), $19 \mathrm{U} / \mathrm{L}$; sodium, $143 \mathrm{mmol} / \mathrm{L}$; potassium $(\mathrm{K}), 3.8 \mathrm{mmol} / \mathrm{L}$; calcium (CA), $8.3 \mathrm{mmol} / \mathrm{L}$; total creatine kinase (Total-CK), $116 \mathrm{U} / \mathrm{L}$; serum creatine kinase myocardial band isoenzyme (CK-MB), $45 \mathrm{U} / \mathrm{L}$; lactate dehydrogenase (LDH), 1,568 U/L; troponin I, $0.39 \mathrm{ng} / \mathrm{mL}$; D-dimer, 6,795 ng/L; international normalized ratio (INR), 2.27; activated partial thromboplastin time (aPTT), 27.7 seconds; blood urea nitrogen (BUN), $15 \mathrm{mg} / \mathrm{dL}$; serum creatinine $(\mathrm{Cr}), 1.0 \mathrm{mg} / \mathrm{dL}$. Serologic tests for hepatitis $\mathrm{B}$ and hepatitis $\mathrm{C}$ were negative. Blood gas values were: $\mathrm{pH}, 7.372$; partial pressure of carbon dioxide $\left(\mathrm{pCO}_{2}\right)$, $41.6 \mathrm{mmHg}$; (bicarbonate) $\mathrm{HCO}_{3}, 23 \mathrm{mmol} / \mathrm{L}$; base excess (BE), $-1.2 \mathrm{mmol} / \mathrm{L}$. Following the recommendation of the contacted poison control center, gastric lavage was performed again and activated charcoal was given every hour for 6 hours $(0.25 \mathrm{~g} / \mathrm{kg}$ per hour) to reduce the intestinal colchicine absorption. Sodium bicarbonate at a dose of $80 \mathrm{mEq}$ was replaced in 12 hours. Electrolytes and blood gases were monitored every 6 hours. Table 1 shows the results of blood gas monitoring. On the 12th hour of her admission, lactate was $10.4 \mathrm{mmol} / \mathrm{L}$ and $\mathrm{HCO}_{3}<15 \mathrm{mmol} / \mathrm{L}$. The patient developed high anion gap (AG) metabolic acidosis due to lactic acidosis. Hemodialysis was performed because of the patient's insufficient urine output. Intravenous fluids and positive inotropic agents were used for persistent low central venous pressure. On followup of the patient, AST, ALT, Total-CK, CK-MB, troponin I, LDH, and INR rose progressively and PLTs declined (Table 2).
Table I Blood gas monitoring for case I

\begin{tabular}{lllllll}
\hline & $\mathbf{p H}$ & $\mathbf{p C O}_{2}$ & $\mathbf{p O}_{2}$ & $\mathbf{H C O}_{3}$ & $\mathbf{B E}$ & $\mathbf{A G}$ \\
\hline On admission & 7.372 & 41.6 & 49.2 & 23 & -1.2 & 12 \\
I2 hours & 7.391 & 23.0 & 65.3 & 13.7 & -9.1 & 21 \\
24 hours & 7.464 & 23.6 & 53.4 & 16.7 & -6.4 & 16 \\
36 hours & 7.341 & 42.0 & 36.4 & 20.5 & -3.1 & 15 \\
42 hours & 7.225 & 42.2 & 30.6 & 15.0 & -10.4 & 20 \\
48 hours & 7.415 & 31.0 & 46.9 & 20.8 & -3.7 & 21 \\
55 hours & 6.665 & 76.0 & 43.1 & 5.2 & -26.0 & 30 \\
\hline
\end{tabular}

Abbreviations: $\mathrm{AG}$, anion gap; $\mathrm{BE}$, base excess; $\mathrm{HCO}_{3}$, bicarbonate; $\mathrm{PCO}_{2}$, partial pressure of carbon dioxide; $\mathrm{pO}_{2}$, partial pressure of oxygen.

Sinus tachycardia was determined by electrocardiography, and echocardiography revealed normal systolic function of the left ventricle, with an ejection fraction of $50 \%-55 \%$. Peripheral blood smear revealed schistocytes. Blood tests showed raised D-dimer, aPTT, prothrombin time and INR, and decreased fibrinogen. Eventually disseminated intravascular coagulopathy (DIC) developed. Fresh frozen plasma and platelet infusion at a dose of 1 unit per $10 \mathrm{~kg}$ was given. $\mathrm{K}$ and $\mathrm{Ca}$ were also replaced for the treatment of hypokalemia and hypocalcemia. At 42 hours following hospital admission, the patient's general condition worsened. She had a heart rate of $132 \mathrm{bpm}$, respiratory rate of 33 breaths/minute, peripheral oxygen saturation of $94 \%$, a Glasgow coma scale of 12 , and invasive arterial blood pressure was $82 / 51 \mathrm{mmHg}$. Blood gas analyses were $\mathrm{pH}, 7.225 ; \mathrm{pCO}_{2}, 42.2 \mathrm{mmHg}$; arterial oxyhemoglobin saturation $\left(\mathrm{SaO}_{2}\right), 96 \% ; \mathrm{HCO}_{3}, 15 \mathrm{mmol} / \mathrm{L}$; $\mathrm{BE},-10.4 \mathrm{mmol} / \mathrm{L}$. The patient had diffuse abdominal pain, tenderness on palpation, and hyperactive bowel sounds. Blood samples taken from the central venous catheter revealed $\mathrm{WBC}$, $18.220\left(10^{3} \mu \mathrm{L}\right)$; hematocrit, 44.1\%; PLTs, 73,000/ $\mathrm{mm}^{3}$; ALT, $93 \mathrm{U} / \mathrm{L}$; AST, $561 \mathrm{U} / \mathrm{L}$; BUN, $11 \mathrm{mg} / \mathrm{dL}$; Cr, $1.3 \mathrm{mg} /$ dL; Total-CK, 1,415 U/L; CK-MB, 135 U/L; LDH, 6, 105 U/L; troponin I, $34.04 \mathrm{ng} / \mathrm{mL}$; INR, 6.18; aPTT, 157.3 seconds. The patient was thought to have developed lactic acidosis, DIC, and multiorgan failure with rhabdomyolysis due to colchicine intoxication, and supportive treatments (fresh frozen plasma, platelet infusion, nasal oxygen, etc) were continued. Hemodialysis was performed again for decreased urine output (400 cc/day). At 54 hours following hospital admission, cardiopulmonary arrest developed. She responded to resuscitation after 50 minutes, and mechanical ventilation was performed. Blood gas analyses were: $\mathrm{pH}, 6.665 ; \mathrm{pCO}_{2}, 76 \mathrm{mmHg} ; \mathrm{HCO}_{3}$, $5.2 \mathrm{mmol} / \mathrm{L}$; BE, $-26 \mathrm{mmol} / \mathrm{L}$. Because of continuing lactic acidosis, hemodialysis was performed again, and the duration of hemodialysis was prolonged. At 58 hours following her admission, the patient went into cardiac arrest again, remained completely unresponsive to resuscitation, and died. 
Table 2 Complete blood count, coagulation tests, and biochemistry measurements for case I

\begin{tabular}{lllllllllll}
\hline & $\begin{array}{l}\text { PT } \\
(\mathbf{s e c})\end{array}$ & INR & $\begin{array}{l}\text { aPTT } \\
(\mathbf{s e c})\end{array}$ & $\begin{array}{l}\text { AST } \\
(\mathbf{U} / \mathbf{L})\end{array}$ & $\begin{array}{l}\text { ALT } \\
(\mathbf{U} / \mathbf{L})\end{array}$ & $\begin{array}{l}\text { LDH } \\
(\mathbf{U} / \mathbf{L})\end{array}$ & $\begin{array}{l}\text { Total-CK } \\
(\mathbf{U} / \mathbf{L})\end{array}$ & $\begin{array}{l}\text { CK-MB } \\
(\mathbf{U} / \mathbf{L})\end{array}$ & $\begin{array}{l}\text { PLTs } \\
(\mathbf{/ m m})\end{array}$ & $\begin{array}{l}\text { Trop I } \\
(\mathbf{n g} / \mathbf{m L})\end{array}$ \\
\hline On admission & 27.7 & 2.27 & 27.7 & 87 & 19 & 1,568 & 116 & 45 & 250,000 & 0.39 \\
I2 hours & 36.3 & 3.09 & 45.2 & 174 & 24 & 2,905 & 602 & 117 & 209,000 & 5.47 \\
24 hours & 34.4 & 2.91 & 43.2 & 233 & 30 & 3,650 & 704 & 125 & 138,000 & 7.70 \\
36 hours & 40.2 & 3.47 & 67.9 & 297 & 36 & 4,940 & 1,874 & 195 & 113,000 & 16.32 \\
42 hours & 66.7 & 6.18 & 157.3 & 561 & 93 & 6,105 & 1,415 & 135 & 73,000 & 34.04 \\
\hline
\end{tabular}

Abbreviations: ALT, alanine aminotransferase; aPTT, activated partial thromboplastin time; AST, aspartate aminotransferase; CK-MB, creatine kinase myocardial band; INR, international normalized ratio; LDH, lactate dehydrogenase; PLTs, platelets; PT, prothrombin time; Total-CK, total creatine kinase; Trop I, troponin I.

\section{Case 2}

A 17-year-old, $47 \mathrm{~kg}$ female patient with a diagnosis of FMF was admitted to a local hospital with the complaints of nausea and vomiting after taking $9.5 \mathrm{mg}$ or $0.2 \mathrm{mg} / \mathrm{kg}$ (19 tablets of $0.5 \mathrm{mg}$ ) colchicine for suicide attempt. She underwent stomach lavage and treatment with activated charcoal at that facility, and was transferred to our hospital an hour after ingestion. She was conscious, responsive, and cooperative, and she had diarrhea. On physical examination she had a blood pressure of $125 / 55 \mathrm{mmHg}$, body temperature $36.5^{\circ} \mathrm{C}$, respiratory rate 15 breaths/minute, and heart rate 70 beats/minute. The patient was pale and cold, and she had abdominal tenderness on palpation. Other system examinations were unremarkable. She was admitted to the intensive care unit. Her initial laboratory findings in the intensive care unit were WBC, $6.640\left(10^{3} \mu \mathrm{L}\right)$; hemoglobin, $13 \mathrm{gr} / \mathrm{dL}$; hematocrit,

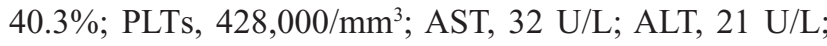
sodium, $139 \mathrm{mmol} / \mathrm{L} ; \mathrm{K}, 4.1 \mathrm{mmol} / \mathrm{L} ; \mathrm{Ca}, 9.5 \mathrm{mmol} / \mathrm{L}$; TotalCK, $112 \mathrm{U} / \mathrm{L}$; CK-MB, $25 \mathrm{U} / \mathrm{L}$; LDH, $156 \mathrm{U} / \mathrm{L}$; troponin I, $0.00 \mathrm{ng} / \mathrm{ml}$; D-dimer, 1,833.78 ng/L; INR, 1.14; BUN, $13 \mathrm{mg} / \mathrm{dL} ; \mathrm{Cr}, 0.7 \mathrm{mg} / \mathrm{dL}$. Blood gas values were: $\mathrm{pH}, 7.48$; $\mathrm{pCO}_{2}, 21.2 \mathrm{mmHg} ; \mathrm{HCO}_{3}, 20.0 \mathrm{mmol} / \mathrm{L} ; \mathrm{BE},-5.9 \mathrm{mmol} / \mathrm{L}$. Following the recommendation of the contacted poison control center, gastric lavage was performed again and activated charcoal was given every hour for 6 hours $(0.25 \mathrm{~g} / \mathrm{kg}$ per hour) to reduce the intestinal colchicine absorption. Blood gas analyses were performed every 12 hours (Table 3). On follow-up of the patient, AST, ALT, Total-CK, CK-MB,

Table 3 Blood gas monitoring for case 2

\begin{tabular}{llllll}
\hline & $\mathbf{p H}$ & $\mathbf{p C O}_{2}$ & $\mathbf{p O}_{2}$ & $\mathbf{H C O}_{3}$ & $\mathbf{B E}$ \\
\hline On admission & 7.48 & 21.2 & 49.4 & 20 & -5.9 \\
I2 hours & 7.369 & 31.7 & 54.1 & 19.1 & -6.1 \\
24 hours & 7.44 & 26.0 & 74.8 & 20.5 & -5.6 \\
36 hours & 7.448 & 26.0 & 74.4 & 20.6 & -4.6 \\
42 hours & 7.418 & 26.2 & 104 & 19.3 & -6.3 \\
48 hours & 7.433 & 32.1 & 45.0 & 22.7 & -2.5 \\
72 hours & 7.395 & 35.6 & 64.8 & 22.2 & -2.1 \\
\hline
\end{tabular}

Abbreviations: $\mathrm{BE}$, base excess; $\mathrm{HCO}_{3}$, bicarbonate; $\mathrm{pCO}_{2}$, partial pressure of carbon dioxide; $\mathrm{pO}_{2}$, partial pressure of oxygen. troponin I, LDH, and INR remained normal (Table 4). Normal sinus rhythm was determined by electrocardiography, and echocardiography revealed the left ventricle had normal systolic function and an ejection fraction of $60 \%$. She did not need hemodialysis and was transferred to the internal medicine service on the fifth day of her admission. The consultant psychiatrist diagnosed a depressive episode as the underlying cause for her suicide attempt. She recovered without sequelae and was discharged on the seventh day of her follow-up.

\section{Discussion}

Colchicine is a drug which for many years has been routinely used for prevention of both acute attacks of FMF and amyloidosis. Colchicine and its metabolites are excreted mainly in the urine and in the bile. Liver hydrolysis certainly occurs, although other pathways may exist. ${ }^{5}$ Due to the high biliary concentration, enterohepatic circulation is presumably the main cause of intestinal distress in acute and chronic poisoning. In patients with hepatic insufficiency, renal excretion is dominant. ${ }^{6}$ Besides colchicine's minor therapeutic index, its potential as a toxic agent has raised concerns over its pharmaceutical use. ${ }^{7,8}$ Although it is not common, colchicine intoxication may cause mortality. Intoxication by colchicine causes the inhibition of cell division at the affected organs by fixing the intracellular tubulin and arresting their polymerization into microtubules. Thus, mitosis and transport systems within the cells are disrupted. Organs which have a high rate of cell turnover, such as the gastrointestinal tract and bone marrow, are the ones most affected. ${ }^{9}$ The symptoms of intoxication can be classified in three phases. Phase 1: early gastrointestinal symptoms, volume depletion, and hypotension resulting from severe vomiting and diarrhea, and peripheral leukocytosis; phase 2: (generally 24 to 72 hours) mental status change, oliguric renal failure, hematopoietic problems, electrolyte imbalance, acid-base disturbance, and shock; and phase 3: rebound leukocytosis and alopecia. Electrolyte and acid-base imbalances such as metabolic 
Table 4 Complete blood count, coagulation tests, and biochemistry measurements for case 2

\begin{tabular}{|c|c|c|c|c|c|c|c|c|c|}
\hline & $\begin{array}{l}\text { PT } \\
\text { (sec) }\end{array}$ & INR & $\begin{array}{l}\text { AST } \\
\text { (U/L) }\end{array}$ & $\begin{array}{l}\text { ALT } \\
\text { (U/L) }\end{array}$ & $\begin{array}{l}\text { LDH } \\
\text { (U/L) }\end{array}$ & $\begin{array}{l}\text { Total-CK } \\
\text { (U/L) }\end{array}$ & $\begin{array}{l}\text { CK-MB } \\
\text { (U/L) }\end{array}$ & $\begin{array}{l}\text { PLTs } \\
\left(/ \mathrm{mm}^{3}\right)\end{array}$ & $\begin{array}{l}\text { Trop I } \\
\text { (ng/mL) }\end{array}$ \\
\hline On admission & 15.1 & 1.14 & 32 & 21 & 156 & 112 & 25 & 428,000 & 0.00 \\
\hline 12 hours & 18.4 & 1.42 & 48 & 26 & 147 & 602 & 117 & 417,000 & 0.01 \\
\hline 24 hours & 21.9 & 1.73 & 52 & 32 & 187 & 147 & 37 & 352,000 & 0.00 \\
\hline 36 hours & 18.7 & 1.45 & 50 & 35 & 175 & 141 & 37 & 388,000 & 0.00 \\
\hline 48 hours & 16.3 & 1.24 & 26 & 23 & 214 & 99 & 40 & 325,000 & 0.01 \\
\hline 72 hours & 12.7 & 0.93 & 24 & 36 & 234 & 63 & 21 & 304,000 & 0.03 \\
\hline
\end{tabular}

Abbreviations: ALT, alanine aminotransferase; AST, aspartate aminotransferase; CK-MB, creatine kinase myocardial band; INR, international normalized ratio; LDH, lactate dehydrogenase; PLTs, platelets; PT, prothrombine time; Total-CK, total creatin kinase; Trop I, troponin I.

acidosis, hyponatremia, hypocalcemia, hypokalemia, hypophosphatemia, and hypomagnesemia have been reported. ${ }^{2}$ Metabolic acidosis, which is associated with substantial morbidity and mortality, is a frequently encountered acidbase disturbance in hospitalized patients. ${ }^{10}$ Lactic acidosis is the most frequent cause of metabolic acidosis in hospitalized patients, characterized by a high AG $(>12 \mathrm{mmol} / \mathrm{L})$ with increased serum lactate concentrations $(>5 \mathrm{mEq} / \mathrm{L})$ and often carries a significant risk for mortality. It is commonly associated with clinical situations, such as shock and sepsis as a result of tissue hypoperfusion and hypoxia. ${ }^{10}$ The Case 1 patient developed this acid-base abnormality in the presence of normal tissue perfusion and oxygenation. Many drugs have been implicated in the pathogenesis of lactic acidosis. ${ }^{11}$ Lactic acidosis progresses despite hemodialysis, when blood lactate is produced faster than it is cleared. ${ }^{12}$ As shown in the case report, the hemodialysis must be performed quickly, and the duration of the hemodialysis session must be prolonged when the clinical and biochemical evaluation of the patient shows signs of acidosis. ${ }^{12}$ The rising lactate level and high AG metabolic acidosis in our patient (case 1) were attributed to lactic acidosis, so hemodialysis was performed, and the duration of hemodialysis was prolonged. Lactic acidosis in the first case was one of the reasons for mortality.

Ingestion of high doses of colchicine results in death, but toxicity might be seen within the therapeutic doses. The dose required for morbidity or mortality varies significantly. Bismuth et al reported the correlation between the clinical process and the ingested dose as follows: minor toxicity with $100 \%$ survival after ingestion of less than $0.5 \mathrm{mg} / \mathrm{kg}$ of colchicine, major toxicity (myelosuppression) with $10 \%$ mortality after ingestion of $0.5-0.8 \mathrm{mg} / \mathrm{kg}$ of colchicine, and $100 \%$ mortality (cardiogenic shock and death) after ingestion of $0.8 \mathrm{mg} / \mathrm{kg}$ or more. ${ }^{3,4}$ Conversely, published reports have stated that doses less than $0.5 \mathrm{mg} / \mathrm{kg}$ caused cardiogenic shock and death. ${ }^{13}$ Cardiogenic collapse and myelosuppression are reported as the main causes of mortality, and most of the deaths are seen $7-10$ days after ingestion. ${ }^{14}$ We realized the importance of doses the two cases reported here. The dose of $1 \mathrm{mg} / \mathrm{kg}$ in the first case was directly related with the mortality, while the dose of $0.2 \mathrm{mg} / \mathrm{kg}$ in the second case was related with survival.

The other difference between the patients was the time of hospital arrival after ingestion. This period was 4 hours for case 1 , and only 1 hour for case 2 . As well as the total amount of ingested colchicine, the time between intake and therapeutic intervention also affects survival..$^{15}$ The initiation of treatment later than 2 hours after ingestion of colchicine may significantly impair the treatment course because the absorption time for colchicine after oral administration is about $30-120$ minutes. ${ }^{15}$ However, there are also published fatal cases of colchicine intoxication despite immediate presentation and prompt onset of treatment. ${ }^{16}$ Varying dissolution rates of colchicine tablets, the $\mathrm{pH}$ at the absorption site, and interindividual variations in gastric emptying and enteral motility may be the causes of this difference. ${ }^{17}$ Mullins et al described arrhythmia and cardiac insufficency, ${ }^{13}$ and Sauder et a ${ }^{18}$ described myocarditis associated with colchicine intoxication. Sauder et al reported that the outcome of colchicine poisoning depends on the occurrence of acute circulatory insufficiency and also reported that an early decrease of cardiac output predicts lethality. However, the mechanisms of shock in acute colchicine poisoning are uncertain; several factors may be important. These are: 1) hypovolemia, mostly due to the intestinal loss of water by diarrhea, ${ }^{18} 2$ ) the presence of metabolic acidosis, and 3) depressed myocardial function due to the secretion of Myocardial Depressant Factor. ${ }^{18}$ In case 1, despite aggressive fluid resuscitation and vasopressor infusion, the patient died after a sudden cardiovascular collapse. Stapczynski et al reported two fatal cases following acute ingestions of $12 \mathrm{mg}$ of colchicine. ${ }^{19}$ Like our patient, both of these patients had early leukocytosis $\left(25.3 \times 10^{3}\left[\mathrm{WBC} / \mathrm{mm}^{3}\right]\right.$ and $42.6 \times 10^{3}$ $\left[\mathrm{WBC} / \mathrm{mm}^{3}\right]$, respectively) and died of sudden asystole within 24 hours of presentation. Mullins et al also showed early 
leukocytosis in their two fatal cases. ${ }^{13}$ We propose that early leukocytosis may be a predictor for mortality. The intoxication causes excessive fibrinolytic activity. ${ }^{20}$ Excessive fibrinolytic activity and multiorgan failure were the factors which may have contributed to the formation of DIC in our patient.

A specific experimental treatment (Fab fragment antibodies) for colchicine poisoning has been used, although it is not commercially available as yet. ${ }^{21}$ Gastric lavage and activated charcoal are used to prevent absorption in colchicine intoxication, but the main treatment is supportive therapy; it is very important to compensate for initial fluid loss. The use of central venous pressure monitoring of hemodynamic status as an indicator for directing supportive therapy has been proposed. ${ }^{13}$ In our patient, the treatment of circulation and multiorgan failure, consisting of fluid resuscitation and inotropic support, were arranged according to central venous pressure monitoring and urinary output.

\section{Conclusion}

Colchicine intoxication is a severe, life-threatening situation and patients should be monitored closely in intensive care units. The ingested dose and arrival time to hospital play a critical role in the treatment. Invasive hemodynamic monitoring must be done if there is shock, necessitating intensive fluid and inotropic therapy, and also if there is multiorgan failure.

\section{Disclosure}

The authors report no conflicts of interest in this work.

\section{References}

1. Levy M, Spino M, Read SE. Colchicine: a state-of-the-art review. Pharmacotherapy. 1991;11(3):196-211.

2. Murray SS, Kramlinger KG, McMichan JC, Mohr DN. Acute toxicity after excessive ingestion of colchicine. Mayo Clin Proc. 1983;58(8): 528-532.

3. Bismuth C, Gaultier M, Conso F. [Medullary aplasia after acute colchicine poisoning. 20 cases]. Nouv Presse Med. 1977;6(19):1625-1629. French.
4. Bismuth C, Baud F, Dally S. Standardized prognosis evaluation in acute toxicology its benefit in colchicine, paraquat and digitalis poisonings. J Toxicol Clin Exp. 1986;6(1):33-38.

5. Hunter AL, Klaassen CD. Biliary excretion of colchicine. J Pharmacol Exp Ther. 1975;192(3):605-617.

6. Bain LS, Galloway DB, Petrie JC, Wood RA. Gout. Br Med J. 1974;1:446-448. Available from: http://www.jstor.org/discover/10.2 $307 / 25422985$ ?uid $=3739192$ \&uid $=2 \& u i d=4 \&$ sid $=21102939248027$. Accessed November 11, 2013.

7. Ashrafuzzaman M, Tseng CY, Duszyk M, Tuszynski JA Chemotherapy drugs form ion pores in membranes due to physical interactions with lipids. Chem Biol Drug Des. 2012;80(6): 992-1002.

8. Ashrafuzzaman M, Duszyk M, Tuszynski JA. Chemotherapy drugs thiocolchicoside and taxol permeabilize lipid bilayer membranes by forming ion pores. J Phys Conf Ser. 2011;329:012029.

9. Güven AG, Bahat E, Akman S, Artan R, Erol M. Late diagnosis of severe colchicine intoxication. Pediatrics. 2002;109(5):971-973.

10. Adrogué HJ. Metabolic acidosis: pathophysiology, diagnosis and management. J Nephrol. 2006;19(Suppl 9):S62-S69.

11. Liamis G, Milionis HJ, Elisaf M. Pharmacologically-induced metabolic acidosis: a review. Drug Saf. 2010;33(5):371-391.

12. Avc1 D, Çetinkaya A, Karahan S, et al. Suicide commitment with metformin: our experience with five cases. Ren Fail. 2013;35(6): 863-865.

13. Mullins ME, Carrico EA, Horowitz BZ. Fatal cardiovascular collapse following acute colchicine ingestion. J Toxicol Clin Toxicol. 2000;38(1):51-54.

14. Harris R, Marx G, Gillett M, Kark A, Arunanthy S. Colchicineinduced bone marrow suppression: treatment with granulocyte colony-stimulating factor. $J$ Emerg Med. 2000;18(4):435-440.

15. Wallace SL, Ertel NH. Plasma levels of colchicine after oral administration of a single dose. Metabolism. 1973;22:749-753.

16. Milne ST, Meek PD. Fatal colchicine overdose: report of a case and review of the literature. Am J Emerg Med. 1998;16:603-608.

17. Wasserscheid K, Backendorf A, Michna D, Mallmann R, Hoffmann B. Long-term outcome after suicidal colchicine intoxication in a 14-yearold girl: case report and review of literature. Pediatr Emerg Care. 2013;29(1):89-92.

18. Sauder P, Kopferschmitt J, Jaeger A, Mantz JM. Haemodynamic studies in eight cases of acute colchicine poisoning. Hum Toxicol. 1983;2(2):169-173.

19. Stapczynski JS, Rothstein RJ, Gaye WA, Niemann JT. Colchicine overdose: report of two cases and review of the literature. Ann Emerg Med. 1981;10(7):364-369.

20. Brvar M, Ploj T, Kozelj G, Mozina M, Noc M, Bunc M. Case report: fatal poisoning with Colchicum autumnale. Crit Care. 2004;8(1) $56-59$

21. Baud FJ, Sabouraud A, Vicaut E, et al. Brief report: treatment of severe colchicine overdose with colchicine-specific Fab fragments. $N$ Engl J Med. 1995;332(10):642-645.
Therapeutics and Clinical Risk Management

\section{Publish your work in this journal}

Therapeutics and Clinical Risk Management is an international, peerreviewed journal of clinical therapeutics and risk management, focusing on concise rapid reporting of clinical studies in all therapeutic areas, outcomes, safety, and programs for the effective, safe, and sustained use of medicines. This journal is indexed on PubMed Central, CAS,

\section{Dovepress}

EMBase, Scopus and the Elsevier Bibliographic databases. The manuscript management system is completely online and includes a very quick and fair peer-review system, which is all easy to use. Visit $\mathrm{http}: / / \mathrm{ww}$.dovepress.com/testimonials.php to read real quotes from published authors. 